\title{
THE MEANING OF SOUTH AFRICAN MEDIA'S EXPANSION INTO THE REST OF AFRICAN SPACE
}

\author{
Musa Ndlovu \\ University of Cape Town \\ musawenkosi.ndvolu@uct.ac.za
}

\begin{abstract}
Focusing on South African media in Africa as a case study, this article argues that national media regionalisation of those economically dominant countries located geo-politically in the southern hemisphere is paradoxical. On the one hand, it follows the same liberal economic expansionist logic as their Western media counterparts and can pose a serious threat to the development of the national/local media of the recipient countries. On the other, it can foster new forms of cooperation among developing countries in the areas such as programme exchange and local media content production. Despite some advantages, the paper argues, these expansions and particularly the South African ones can function as intermediaries for extension of various forms of Western media and cultural imperialism(s).
\end{abstract}

Keywords: Africa, de-colonisation, media imperialism, media, South African media. 


\section{Introduction}

South African media's regionalisation into the rest of the African geo-political and socio-cultural space provides an indispensable case study in exploring mediated time and space reconnection of the African Continent. The northward expansion of South African-based media is, in essence, a transformation of a used to be territorially-bound media- within a particular geopolitical spatial framework (nation-state)- into media platforms available almost across the African continent space. For the purposes of this paper, this process is hereafter referred to as South African national media regionalisation. The meaning of this regionalisation has so far received very limited scholarly attention, despite the continuing growth and possible impact of South African media in the African space. Therefore, to explore this meaning this paper locates South African national media regionalisation in Africa broadly within other comparable regional expansions such as the ones in Asia, Latin America and the Middle East.

The paper does this to argue that national media regionalisation of those economically dominant countries-located geo-politically in the southern hemisphere-is paradoxical. On the one hand, it follows the same liberal economic expansionist logic as their Western media counterparts and can pose a serious threat to the development of the national/local media of the recipient countries. On the other, it can foster new forms of cooperation among developing countries in the areas such as programme exchange and local media content production. Although there generalizable patterns in the manner that national-bound media conglomerates have regionalised and internationalised their operations and media contents, regionalisation of South African media is culturally different. 
South African media content, especially popular and high cultural media products, are hardly 'South African'. While we might cautiously speak of typically India's Bollywood movies and LatinAmerican telenovelas in their respective regions and in the Diaspora, it is difficult to speak of any enduring media product forms and formats that are idiosyncratically South African.

Also, unlike in Latin America, Asia, Middle East, and North Africa, southern African-based regional media expansion scarcely seriously foster any new forms of cultural and linguistic cooperation among other developing countries such as programme exchange.

Regionalisation of South African media does not create space for the development of indigenous languages; it, however, enhances the hegemony of colonial languages such as English, French and Portuguese.

South African media regionalisation in southern Africa may not necessarily be imperialistic on its own, but it definitely functions as an intermediary for extension of various forms of particularly western media and cultural imperialism(s).

The flow of entertainment and informational programmes from South African regional media is uni-directional and is not counterbalanced by media material from other African states.

Lastly, the paper argues that South African media regionalisation is biased in favour of South Africa and inimical to the spirit of New World Information and Communication Order through which southern countries collectively campaign for equitable flow of international information. This paper's subject matter is pursued for the following rationale.

\section{Rationale}

South African media's advance into the rest of African space, unlike that of developed countries' media, is configured largely by 
intra-national political, historical and socio-economic developments of South Africa itself, a developing country situated not in the geopolitical north, but in the southern hemisphere.

This geo-political location coupled with shared class- and racebased historical negative sentiments against Western imperialism and colonisation- cause some South African media (SABC Africa) to perceive their northward expansion, not as media re-colonisation of Africa, but as concrete realisation of south-south cultural solidarity as conceived in New World Information Order (NWICO). This difference of South African media's regional expansion then contributes another critical dimension into study of international communication.

International communication field, scholarly, overwhelmingly examines the domination of southern nations' information and cultural spheres by Western media, especially American media products. In this regard, the field traditionally employs theoretical frameworks such as cultural imperialism (Galtung), media imperialism (Lee), cultural domination. (Schiller), cultural dependency (Boyd-Barret), cultural synchronisation (Hamelink), reversed cultural imperialism (Tomlinson) or cultural globalisation (Servaes, Lie and Terzis).

South African media expansion into African space, then, destabilises conceptual validity of some of these theoretical assumptions and analytical frameworks through which the field of international communication continues to assess the power balance of global communication flow. Cultural imperialism alone, for example, points to this weakness as it presumes a centralized approach to the development of and distribution of media products

The thinking here is that all media products originate from only center nations that have devious ulterior motives of deliberately 
wanting to dominate the media of periphery nations. This belief is based partly on the view that no periphery country will ever be able produce media products of its own (White 4).

Besides, there is just generally insufficient discourse, if any, pertaining to the conceptual efficacy of these theoretical frameworks for elucidating intra-regional expansion of Southern-based dominant media- be it in the geo-political regions of Africa, Latin America, Middle East or Asia. Equally, the inadequacy or absence of such discourse renders difficult conclusions on whether the said theoretical frameworks can suitably explain other regions sufficiently than others given historical differential media developments in each of these regions.

Consequently, situating South African media's northward expansion within these various theoretical assumptions and analytical frameworks is daunting. These theoretical frameworks barely provide for political economic structural transformations in the traditionally centre-periphery dichotomy. This is despite the empirical reality that point to some of the peripheral economies increasingly becoming centres in their respective geo-political regions-as South Africa does.

Where the role of developing world's regional media is interrogated, examiners focus mainly on these media's potential to offer strong competition to Western-produced or influenced programming and media products. Developing world media's promotions of nationally- or regionally-produced cultural products are perceived as reversal of cultural imperialism and/ or internationalisation of local cultures they carry (Borman and Schoonraad; Servaes, Lie and Terziz; Straubhaar and Viscasillas; Sinclair; Tomlinson).

Missing in these analyses, however, is the threat to local or national media posed by regional expansion of southern-based 
dominant media. Some regional media have, arguable, potential to establish new various forms of media or cultural imperialism or synchronisation among the nations of the south, which can be masqueraded in the notions of counterbalancing Western media influence, reversing cultural imperialism, south-south cooperation, geo-linguistic commonalities (usually created by common colonial languages), globalisation of local cultures or even African Renaissance. The transformation, therefore, of national media in the south into regional media is important to understand. The reason for this is that South African media regionalisation is not a humanitarian venture but strategic and calculated capturing of African media markets.

\section{Why African media markets?}

South African media conglomerates are fully aware of the challenges and opportunities presented by the media market conditions in the African continent. The advantage for the South African media is that there is greater need for diverse forms of media entertainment and credible and objective news in some parts of Africa. In these parts, "state-owned TV is seen as the government's mouthpiece and is watched mainly for local news" (SABC Africa \& Africa2Africa Strategic Planning Session Report 3). Multinational broadcasting services are perceived as presenting Africa in a negative light or from a Western perspective (s).

South African media owners are also aware that-following the continuing deregulation and liberalisation of the airwaves in Africa-there is an increase in number of commercial stations being established and new business with which they can form partnerships (Lawal 1-2). However, news and information output of these commercial stations are said to be usually either a re-broadcast of 
the national news, or that of an international broadcasting service or news agency (Jensen 183). The South African Broadcasting Corporation's (SABC) assessment of the broadcast and market conditions in Africa, for example, is indicative of how local media giants generally think about these markets. The SABC notes that:

- Many multinationals are entering Africa, which they now view as a region rather a desperate conglomeration of countries.

- In terms of population, African countries offer a huge market.

- Size of the cities and buying power cannot be underestimatedLagos, Harare, Abidjan combined has 36-million people, versus 10-million in Paris, Rome and Zurich.

- Nigeria alone has a population of over 10-million and over 6.1-million TV sets.

- There is increased television penetration - with improved electrification, satellite technology, cheaper sets as well as battery-operated TV sets.

- In most countries, the TV signal (especially new players) is distributed to the major cities only - satellite is used to cover wider coverage.

- The launch of various satellites has opened many opportunities across Africa. Dishes are smaller and cheaper, for instance, satellite technology (Worldspace) will also allow for more stations as well as more variety.

- Cinema is also becoming more active and sophisticated. There is an increased number of static cinema locations and increased are of cinema coverage. There is also increased growth of static cinema among the urban youth market-and more availability of the latest movies in static cinemas.

- Newspapers are a powerful medium read by all sectors of these markets. 
- Many countries are becoming increasingly open-minded about programming, thus improving the choice of programming. However, religious sensitivities are high in countries.

- Sports programmes, especially soccer, are highly popular.

- $\quad$ Sitcoms, soaps and talk shows work well, especially for female audiences.

- Kids watch cartoons, comedy movies and music programmes.

- $\quad$ Religion strong-sex, bad language, swearing and violence are not usually well received. (SABC Africa and Africa2Africa's Strategic Planning Session Report 2-3)

Though this SABC strategic planning session points to much of the thinking about African markets from a South point of view, systematic media regionalisation has been happening for quite some time in other southern hemisphere-based regions such Latin America and Asia. There are political economic factors that support this form of media regionalisation.

\section{Media Regionalisation}

Historically, the developing countries of Africa, Asia, Middle East and Latin America are neither homogenous nor similarly marginalised (Shaw 275) in the global political economy. Consequently, the growth of these countries' national media industries, intra-regionally and extra-regionally, is also not at the same pace and/or level of technical sophistication. Comparatively, some developing economies in each of these regions have far developed media industries than others. Those economies with better-developed media industries-and similar to their Western counterparts in developed capitalistic economies, have employed them for production of cultural programmes for both national and regional consumption. 
In the developing region of Latin-America, for example, Brazil's Globo and Mexico's Televisa, are noted to be major commercial producers and exporters of television programmes for consumption in their region. Mexican Televisa, a private media conglomerate, does not only dominate its national and regional audiovisual market, but has also monopolised Spanish-language television throughout the United States and Europe. Competing with Televisa in this market is a Brazilian-based TV Globo; TV Globo is also one of the word's biggest television networks outside of the US (Sinclair 344). Globo and Televisa not only export media programmes, but also transmit them via satellite into intended regions. Other major exporters of television programmes in the Latin-American region are Venezuela's Cisneros and Argentina’s Clarín. Smaller Latin-American nations, however, such as the Dominican Republic remain net importers of television programmes (Straubhaar and Viscasillas 192; Kareithi 8).

In Asia, the Hong Kong based Television Broadcasts (TVB) has grown into a superstation that transmits its programs via satellite to as many as forty countries ranging from Taiwan, Malayia and Indonesia to Vietnam and even China (Chadla and Kavoori 426). In the South Asian context, observes Chadla and Kavoori (2000), India's Zee TV plays the similar role as TVB. Films produced in India and characteristically also show Indian culture have also grown significantly in the global market (Pendakur and Subramanyam).

Similarly in the Middle East and in North Africa those economically strong countries and/or or those countries with a longer broadcasting/media history have dominated other nations in these regions, particularly in the development of international television services. This is witnessed in the launching of Egyptian Space Chanel, Saudi Middle East Broadcasting Center, Kuwait Space Channel, the Jordanian Arab Space Channel, Space Network of 
Dubai, Tunisia TV7, Moroccan Satellite Channel, Oman TV, United Arab Emirates TV, etc (Amin 101).

However, of the Middle Eastern-based satellite television networks, Al-Jazeera is increasingly becoming far more visible and re-defining the balance of communication power in the global communication system, and posing a challenge to the likes of Skynews, BBC and CNN. Parallel to these trends in the global and regional satellite television sphere is South African broadcasters' aggressive expansion in the African continent.

\section{South African Broadcast Media Expansions: Multi- choice and SABC}

A repercussion of the South African rush to privatise is that county's dominant position in satellite broadcasting continent wide. (Paterson 578)

In the sub-Saharan region of Africa, South African broadcast media is also making significant inroads, compared to its regional counterparts. The South African broadcasting Corporation and MIH Group/MultiChoice/Naspers-which owns M-Net-have been more aggressive in regard. On $1^{\text {st }}$ October 1986, South Africa launched its first pay, private subscription television service-Electronic Media Network (M-Net), which later expanded into African broadcast markets. M-Net began as an individual pay-channel and it has, however, over the years undergone immense growth, including the launch of its international service into Africa in 1992. The growth into Africa via terrestrial rebroadcast began in Namibia in 1992, with countries such as Botswana, Ghana, Nigeria, and Egypt following (CMNALL-E301). M-Net is said to have more than 1,23 million subscribers in forty-one countries across the African continent. 
The main M-net channel focuses on films and sport, but also offers a general entertainment line-up of children's programmes, series and magazine programmes. (CMNALL-E301; South African Year Book 2001/2). It's Africa oriented brands/channels are M-Net Africa, M-Net Hausa, M-Net Yoruba, Africa Magic, Africa Magic Plus, etc. In 1995 M-Net launched the world's first digital direct-to-home subscriber (DTH) satellite service called DStv which carries over thirty video channels and forty audio programmes on C-band to the whole of Africa and on low-cost KU-Band to Southern Africa south of Lusaka (Jensen 183). M-net is part of the South Africa-based Multichoice (MIH Group) which owns Multichoice Africa.

Multichoice Africa is an extension of this South African media conglomerate and is tasked with providing multi-channel pay television and subscriber management services in 48 countries in Sub-Sahara Africa. The group has ownership interests through MultiChoice Africa in joint ventures operating in Kenya, Ghana, Uganda, Nigeria, Tanzania, Zambia, Namibia and Botswana. In other Sub-Saharan African countries, MultiChoice Africa operates through agents or franchisees. It is only through pay TV broadcast services that Multichoice/MIH Group is taking over the African continent; is also through its new mobile and internet serves.

South African national media's commercial, Africa-oriented regional expansion is not only propelled by commercial broadcasters (and some major print titles), but by the country's public service broadcaster as well-the SABC. The SABC's regional expansion is both in the form of radio and television services. In the early 1990s, SABC launched Channel Africa, a radio service aimed at audiences in Africa and Indian Ocean Islands. Channel Africa is said to be providing radio programmes with a specifically African content (South African Year Book 2001/2 123). It broadcasts programmes in 
English, French, Kiswahili and Portuguese. In September 1995, the SABC implemented a DBS service offering more than three channels (Paterson, 1998). Continuing to advance in Africa, in 1998, the $\mathrm{SABC}$, in conjunction with Multichoice Company, launched its two Africa-oriented pay-channels: SABC Africa and Africa2Africa, on DStv bouquet.

\section{Africa2Africa}

Although, as shown above, the SABC has gradually been enhancing its presence in the African broadcast media markets, it brought its subscription channels-Africa2Africa and SABC Africainto the international broadcasting scene only recently-in 1998. These channels aim to be different to both South African and other foreign channels broadcasting into African media space. Both Africa2Africa and SABC Africa channels intend to be leading content providers in Africa. They respectively also aim to provide entertainment programmes produced either for Africa, about Africa or by Africa and bring African news to Africa, from Africa.

In November 1998 SABC launched its first ever subscription entertainment-oriented channel called Africa2Africa. This channel became the first satellite channel to broadcast exclusively a variety of African programmes directly into the homes of DStv subscribers across the African continent and other parts of the world.

Seventy-five percent of Africa2Africa's programming, however, originates from SABC archives. This is supplemented by only twenty-five percent programming drawn from the rest of Africa. Africa2Africa programming is subdivided into eight-hour blocks, which are repeated three times per day to complete a 24-hour cycle. Seventy percent of the SABC-produced programmes broadcast on Africa2Africa are said not be currently broadcast on any of the 
SABC's domestic free-to-air channels: SABC1, SABC2 and SABC3. (Africa2Africa). Of this seventy percent are a variety of mainly South African-produced situation comedies, dramas, mini-series, music, children and documentary programmes. Africa2Africa broadcasts in English; it also provides material in French, Portuguese and a variety of African languages.

For the $\mathrm{SABC}$, the rationale for launching Africa2Africa is to provide African-oriented and alternative programming, which is aimed at counterbalancing foreign images and satellite channels now available to television viewers in the African continent. Furthermore, the SABC is of the view that the available satellite channels only promote African filmmaking and general programme production, but do not provide African-centric programme content on 24-hours basis to DStv subscribers. In this respect, the SABC did not limit itself only to an entertainment channel; it also launched a news channel called SABC Africa.

\section{SABC Africa}

The SABC Africa channel was also launched in 1998 by the SABC in conjunction with MultiChoice. It is news and information-oriented subscription channel available 24-hours per day on DStv bouquet and SABC2, one of SABC's three domestic free-to-air channels.

The rationale for the introduction of SABC Africa, according to the $\mathrm{SABC}$, is to bring African news to Africa; to provide a channel whose news reporting is not limited to catastrophe reporting, but also include development stories and good news. By introducing this channel, the $\mathrm{SABC}$ also aims to nurture and stimulate emerging democracies (SABC Africa).

SABC also wants to use SABC Africa channel not only as a provider of news, but also as news source for local and international 
news market. The SABC is planning to "open up avenues for news gathering throughout the African continent by setting up news gathering bureaux and employing stringers" (SABC Africa). However, so far, SABC Africa uses its existing news infrastructure. These intentions reveal that the SABC wants to grow in the African news and entertainment markets. Though the growth of African broadcast is more aggressive than other media, print media is making inroads.

\section{Print Media: Avusa and Media24/MIH Group}

South African print media is also an indication that South African media conglomerates intend to make what used to be nationally-bound print media products borderless and regionally accessible. Media24 (part of Multichoice) and Avusa (formerly known as Johnnic Communications) are the two main South African media organisations making serious moves in the African markets. Following Media24's launch of Kickoff Nigeria in 2002, Johnnic Communications acquired fifty-one percent stake (fiftyfive percent equity) in BusinessDay Nigeria. Other newspaper and magazine titles owned by these two media giants can be found in several countries in the continent. For example, Sunday Times, BusinessDay, Sunday World, and Financial Mail (all Avusa) as well as City Press, Beeld and Rapport (all Media24 Group)-can be found in various countries in southern Africa: Botswana, Namibia, Zambia, Swaziland, Zimbabwe, Lesotho, etc.

Of South African media in the continent, Media24 group is the leading company. It is the largest publisher of magazines and newspapers and a printer, and also a distributor of magazines, newspapers and related products in Africa. Media24 is also the holding company for the book-publishing and distribution business, 
Via Afrika. Via Afrika is one of the leading African educational and general book publishers. Via Africa have footprints in Botswana, Namibia and Zambia. In view of these developments, the following question is worth asking?

\section{Is South African media regionalisation reconnecting the Afri- can continent?}

Of course South African media regionalization is contributing to the reconnection of the African continent. The question is not if but how South African media is reconnecting the continent, time and space wise. South African media contributes to the volume, spread and availability of various news, sport, music and other values to different audiences situated in different parts of the African continent. For example, a person seating in Gaborone could be reading the very same South Africa Friday paper, The Mail and Guardian, as the person in Nairobi. The same could be said of persons who could simultaneously be watching SABC international or Supersport on DStv. The issue here is that South African media available in the African continent space overwhelmingly carries western media products or South African news. In essence, South African media is rather "reconnecting" the African continent through American and European-developed media technologies and popular cultural products in the process of expanding its continent-wide footprint. Regionalizing print media largely contains South African news stories. Is regionalization of South African media re-connecting the continent though re-colonizing or de-colonizing its cultural and information space?

\section{De-colonization of African cultural and informational space}

Integral to the wide-ranging anti-colonial struggles of the nineteenth and successive centuries that characterised the former 
colonies and/or developing nations was (and still is) a concerted effort to decolonize their cultural/information spheres. Decolonization of this sphere involved a critical assessment of the role of Western cultural and informational media products in creating, maintaining and expanding colonial structures in the colonies and in nurturing the colonial legacy in the post-colonial new states. Continued dependence of post-colonial states' media on Western-controlled news and entertainment organizations was considered to be antithetic to the emergent nations' quest for total autonomy in all of their spheres. This consideration took mainly two dimensions: quantitative and qualitative.

At the quantitative level, the contention revolved around the vast flow of media programmes, news and information from the advanced Western countries to the emergent nations, especially from the beginning of the nineteenth century (Musa 118). It was contended that the flow of entertainment and informational programmes from developed countries was uni-directional and was not counterbalanced by media material from the media of new states. Comparatively, in the news front, little was said about the so-called Third World countries in the Western media.

At a qualitative level, the content of media programmes imported from developed countries' media industries became the subject of scrutiny as well. Western-controlled news agencies, besides underreporting the activities of the countries of the south, presented reports that were mainly riddled with negativities such as crime, scandals, disasters, corruption, and other social ills. Positive news about the happenings in the developing nations was scarce. Such parochial and negative imaging and reporting increased concerns in the developing nations about the role of Western-controlled news agencies such as Reuters, Associated Press (AP), United Press International (UIP) and 
Agence France Presse (AFP) in the international news flow, as well as in maintaining a biased socio-cultural, economic and political ideology of the West.

The contents of the Western-produced entertainment-oriented media programmes were also subjected to examination from qualitative dimension. These popular cultural media programmes are still seen to be promoting Western cultural mannerisms. Further, their abundance in the developing nations' media is seen to be detrimental to the cultural integrity of the populace of these nations at national, regional and local levels.

In a nutshell, the behavior of the Western media organizations is seen to be creating conducive to the re-colonization of developing nations by developed nations in terms of information and culture. Concerns of this nature have lead to the adoption of reactionary and corrective measures by the developing countries such as, among other initiatives, the formulation of New World Information and Communication Order (NWICO) under the auspices of the United Nations Education, Scientific and Cultural Organisation (UNESCO). NWICO is part of the attempts to de-colonise the cultural/ information sphere in the south.

\section{New World Information and Communication order (NWICO)}

The New World information and Communication Order was proposed to address matters related to:

- the imbalance of international flow of news, information and media entertainment;

- inequities in the arena of international communication;

- the crucial role of communication in economic and social development; and 
- the right to national self-determination of domestic communication policies (Fourie and Oosthuizen 416)

Primary to NWICO is the restructuring of the international media and telecommunication system to allow developing nations to obtain greater influence over their media, information, economic, cultural, and political systems (McPhail). According to the Developing nations, the current international media and telecommunication system is a consequence of prior colonial patterns reflecting commercial and market imperatives. "NWICO provides a way to remove this vestige of colonial control" (McPhail 9).

NWICO calls for de-colonisation of the developing nations' cultural/information spheres and for the democratisation of the world communication system, where all people would have equal access to information central to their social and economic development. The current world communication system, according NWICO proponents, limits these opportunities. Instead, it is a system that commercialises media institutions, commoditise information at the expense of public interests and limit access to information for multitudes. In a nutshell, during 1970s and 1980s the NWICO arose as direct response to what is called media imperialism, a concept closely related to cultural imperialism (Fourie and Oosthuizen 416).

\section{Media and Cultural Imperialism}

The concepts of media and cultural imperialism, though not meaning exactly the same thing, are predominantly used in the field of international communication as analytical concepts, especially in the examination of the manner in which trans-national media industries of the developed nations exercise dominance over the cultural/information sphere of their developing counterparts. In the examination of the manner in which this dominance is exercised, 
media and cultural imperialism are applied to a number of international media and communication-related aspects that are said to be instrumental to Western dominance and southern dependence. Central to the employment of these concepts, therefore, is to assess and demonstrate the balance of various layers of power among the global information institutions; means of information transmission; and in the flow information itself.

As analytical frameworks, the concepts of media and cultural imperialism are used to interrogate subjects relating to foreign Direct Broadcast Satellite (DBS); ownership of developing nation's media outlets by the West through direct investment, transnational advertising; imbalance in the broadcast spectrum allocations; international communication policy; the dependence of developing nations' media on the technology manufactured from developed nations; the employment of Western personnel or personnel trained in these countries and the dependence on developed countries' media institutions and agencies for entertainment and news products (Golding and Harris; Gher; Kumar; McPhail).

These concepts have as well attracted several definitions. However, only two are considered here because of their close relation to others that have been developed and because of their importance in the unfolding of this paper. Lee (68) defines media imperialism as television programme exportation to foreign countries; foreign ownership and control of media outlets; transfer of the 'metropolitan' broadcasting norms and institutionalisation of media commercialism at the expense of public interest; and invasion of capitalistic world views and infringement upon the indigenous way of life in the recipient nations.

Schiller defines cultural imperialism as 
The sum of processes by which a society is brought into the modern world system and how its dominating stratum is attracted, pressured, forced, and sometimes even bribed into shaping social institutions to correspond to, or even promote, the values and structures of the dominating center of the system. (9)

Closely associated with the concepts of media and cultural imperialism is the dependency paradigm (Servaes, Lie and Terzis,). Central to the dependency paradigm is the perception of Western-controlled media as an integral part of media and cultural imperialism and re-colonisation of the developing nation's cultural/ information sphere. Dependency theorists argue that, while the old imperialists control was based on the brutal militaristic power and economic domination, the new imperialism is based on ideological manipulation by mainly Western-based multinational corporations that control the means of communication (Sonderling 201). The invention of and spread of new communication technologies and the expansion of transnational communications industries lead to renewed cultural dependency. Such dependence is described as media imperialism (Servaes 35; Sonderling 201; Stevenson 6).

As a result, however, of multifaceted inter and intra evolutionary transformations in the traditionally geo-political and socio-economic center-periphery regions, both concepts of media and cultural imperialism are loosing their critical bite and historical validity. For present complexities in the international communication scene, they seem to appear misconceived and unresponsive.

Like NWICO, media and cultural imperialism as well as the dependency paradigm see global communication system as favouring the global cultural and political economic objectives of developed northern countries. Their definitions and applications 
tend to reflect the notion of dominance of the developing nations' cultural and information spheres by the developed nations alone. These theoretical assumptions and analytical frameworks fail, to some extent, to accommodate the patterns of media developments in the south that can create conditions of dominance of the south by the south. Their oversight is the extent to which they neglect both the active embrace of market-driven regional media expansion by dominant media houses in the south and the extent of globalisation of local, national and regional cultures by these media. The South African media's regional expansion, then, provides a good case study in this regard.

\section{Discussion and Conclusion}

The foregoing assessment reveals South African media conglomerates' understanding of the political, economic, social, cultural and audience conditions in the African continent. This assessment informs South African media's transformation from being a territorially-bound to regional media players. The impact of this regionalisation is starting to show in some areas.

For example, in his strongly critical article about the SABC, Khandjii observes that: "in Namibia there is a tendency among the national elite of listening more to Channel Africa for news outside the country rather than our local broadcasting services that also report on stories outside our borders" (2). In 2006, research by Tleane revealed that "almost all popular South African magazines, mainly from the Media24 stable...could be found on newsstands in Windhoek. In fact, it was claimed that it is almost impossible for any local (Namibian) magazine to succeed..." (65).

Quite rightly, the Namibian case should not be exaggerated on basis of limited empirical research evidence. Be that as it may, 
it is indicative of the possible negative impact resulting from South African media regionalisation.

If the tendency of the Namibian elite, notwithstanding the individual right to freedom of choice, is indicative of what is happening across the continent, this spells disaster for local national media in respective African nations. The orientation of national elite towards regional media, in this case Avusa, Multichoice and the $\mathrm{SABC}$, in the south can have adverse effects for local underdeveloped media markets in terms of revenue. If affluent audiences for local media shrink and are absorbed by foreign and/or regional media, the local media might eventually fail to sustain their existence against more resourceful regional media, as South African media is. This will not be in the strongest interest of democracy, which is largely premised on diversity.

The consequence of fewer local media means fewer platforms through which locals can exercise their universal right to freedom of expression. Fewer local broadcast platforms limit the number of diverse media voices from which the locals can obtain valuable information. South African media regional expansion, as result, might not be contributing to information diversity and pluralism in the nations where it is targeted.

The other problem is the influence this commercially-oriented regionalisation has on media with public service mandate like the SABC. The SABC case shows that public service broadcasters go fully commercial when they regionalise. SABC is regionalising into poor countries, but it adopts a commercial approach. What makes SABC different from BBC then? This tendency of public service broadcasters, of the both north and south, to abandon their social responsibility or benevolent role and adopt the practices of their commercial counterparts when they regionalise threaten the existence 
of local broadcasters, which carry certain social responsibilities and mandates to their respective nations. This cultivates a culture of the "institutionalisation of media commercialism at the expense of public interest” (Lee 68).

SABC Africa and Africa2Africa channels, for example, neither carry the same universal access and other mandates in their broadcasting in the rest of Africa that govern the SABC nationally, nor even carry the mandates that govern its national commercial broadcasting arm. Most of these mandates, especially the universal access mandate necessitate the easy accessibility of the SABC to the most of the national populace. Since the SABC, then, compromises most of its public service principles and the fact it becomes accessible mostly to the elite few, its presence and advancements in the rest of Africa becomes an act exclusion from the alternative information which it claims to provide for the multitudes of the informationstarved. This is contrary to the spirit of NWICO and what it envisaged of the media in the south.

Another aspect of the transformation of the national media into regional media in the south is that which relates to their presentation of the south in general to the international community. It is alluded to above that the current global media system is biased against the south. However, the manner in which southern regional media present the south in comparison to their northern counterparts is yet to be fully explored. In the case of the SABC's regional expansion and its presentation of Africa, however, Khandjii sees it as no different to the way the West advanced and reported Africa. Kandjii notes that

Parochial reporting and negative imaging is being perpetuated through this regional expansion. For example, the expansion of SABC into the continent is taking the form by which other media outlets such Reuters, BBC and the Voice of America 
of this world have expanded and covered Africa. Just as these outlets have depended on their in-house input to inform and discuss the continent, so has SABC been relying on its own resources and personnel to cover Africa. (2)

Khandjii further points out that

The SABC is in the process of setting up a bureaux on the continent as part of its efforts to establish a commercial wholesale news agency. In this vein, the trend has been for a trickling down effect of news from say this bureau or any city in which the bureaux may be located. What is news for or on Africa is thus the prevailing viewpoint of those managing the bureau and determined by their media organisations. (2)

On the other hand, however, despite these disadvantageous effects of the South African media regionalisation, advantages are emerging. Let's take SABC for example. The fact that the SABC relies on its inhouse input to inform and discuss the continent does not necessarily mean unfair and negative reporting. For example, comparative research done in 1999 showed that SABC 3 news coverage of Africa in the period of between January and February 1999 was mostly fair on its presentation of Africa. The results show that seventy-three percent of SABC 3 stories on Africa were fair, while eleven percent were positive and sixteen percent negative (Bird 26-27). SABC 3 is the only Englishmedium television channel among the SABC's domestic free-to-air news and entertainment channels from whose achieves the SABC Africa channel can mainly source English news, whish is its broadcast medium as well. Also, SABC news tends to be the same on its entire domestic channels (Mapukata unpublished). In short, the SABC is also reporting on the good news about Africa. It could do more.

In August 2002, for example, the SABC's visuals containing the live coverage of the signing of the Democratic Republic of Congo 
peace accord were seen on CNN and on the Belgian broadcaster. Also the launch of the African Union in Durban was carried live on both SABC2 and SABC Africa. More important in this regard is that "a number of countries which could not be in Durban wanted the feed of the broadcast to their nations and asked for permission to down load the SABC feed through their decoders. This was agreed to, at no cost to the nations concerned" (Tsedu 11).

There are important points that need to be made here. The behaviour of the SABC allowed many African media and people to have access to one of the main events marking the changes taking place in Africa. Second, the SABC lived up to, though in a minor way, its claim that reporting of Africa is not only limited to negative reporting, but extends to positive news as well. If the argument had been, for example, that negative reporting about Africa has an impact on foreign investor's perception of the continent; the same should be said of the positive news from the continent.

Another positive role of the SABC's regional expansion is in the area of culture. Although high percentage of cultural programmes shown on Africa2Africa originate from South Africa, the SABC does manage to show other African movies which are characteristically African and do not follow formulas typical of Hollywood and European filmmaking. Africa2Africa channel also plays various African music genres. All these are shown not only to Africa but also to other parts of the world. In this respect, Africa2Africa should be seen as taking African cultures onto the global entertainment arena and adding to the number of platforms on which these cultures can be seen. Lastly, the channel increases the knowledge of African cultures among Africans themselves after decades of isolated co-existence in their continent.

Other advantages can be identified in terms of what Multichoice is doing in the continent. Through the DStv services, MultiChoice 
Africa maintains a strong focus on local content and extensive investments have been made in the creation of content made in Africa for Africa thus showcasing and building local talent.

This, however, should not be exaggerated; more especially, in terms of reversing cultural imperialism approach. The South African media broadcast higher percentages of South African cultural products mostly to African nations, from where 'media and cultural imperialism' did not come. Their broadcasting, therefore, can hardly be considered 'reversal of cultural imperialism' in the same sense that Latin American commercial media conglomerates broadcast mainly regionally-produced cultural material to some Spanish and Portuguese-speaking communities in Europe and America. South African regionalisation is not the same way that India and Egypt export their home-grown movies. Even DStv and M-Net can hardly be said to be reversing cultural imperialism since the highest percentages of their programme content originates from the West. Through them, South African media is a conduit for western media products to the rest of African space.

South Africa, though increasingly becoming a political economic regional 'centre' in its regional global periphery and exporting 'its' media into the rest of the African space, is culturally 'different' to Latin-America and India. South African media content, especially popular and high cultural media products, are hardly 'South African'. While we might cautiously speak of typically India's Bollywood movies and Latin-American telenovelas, it is difficult to speak of any enduring media product form that is idiosyncratically South African.

Furthermore it is not only 'reversal of cultural imperialism' approach that is limited when applied to some cases of regional expansion in the south, but cultural and media imperialism as well. Central to the notion of media and cultural imperialism is the 
invasion of indigenous cultures by alien foreign values and media. This notion implausible when applied to the SABC case since it broadcasts African cultures to African people and who at the same time are mostly urbanised middle class. The SABC's re-localising of the African middle class through provision of African-centric cultural products should hardly be considered culturally imperialistic. The same, however, cannot be said of DStv and M-net- except with regard to the platform they provide for African movies.

Indeed the South African media is not introducing new 'metropolitan' broadcasting norms as colonial era broadcasters could be argued. Neither does it bring African countries to the 'modern world system, which they are already not in. Also, dependency paradigm, media and cultural imperialism, plausibly view the current global communication system as an outgrowth of colonial patterns based on Western nations' brute power of military and economic domination. The same, however, cannot necessarily be said of $d$ of South African media's scope and nature of regional expansionism, despite South Africa worrying domination in other areas in the continent.

In this context, even Hamelink's (1983) concept of cultural synchronisation is both illuminating and limited. It is illuminating in the sense that it makes provision for cultural synchronisation taking place without imperialistic relations constituting the prime causal factor or even without any overt imperialistic relations. Since South Africa is arguably no imperialistic power, the South African media's regionalisation can be accommodated in this line of thinking. However, cultural synchronisation concept is limited in the sense that, as much as it dismisses the cultural impact of colonialism, it still retains the notion of the 'metropolis-satellite' structure, which does not exist in the cases of southern-based regional media relationships. 
Further, as much as South African media cultural products go massively to and without reciprocation from fellow African nations, there is a danger of exaggerating their effects if it is to be argued that they can have a 'synchronic mode' and can destroy cultural autonomies of the receiving countries.

On the other hand, what needs to be noted as well is that, despite some of the advantageous results of South African media's expansion in Africa, its interests are strategically commercial, although it downplays this fact. The SABC, for example, conveniently downplays the commercial motive as the main reason behind its regionalisation. It presents its channels as if they are vehicles through which Africans can reclaim their information/cultural sphere from Westernproduced media material.

Despite real and self-serving advantages that various South African media platforms can be said to have in the continent, these products are beyond the reach of the multitudes in Africa. Newspaper and TV subscription fees are expensive. Given the technological and financial means through which South African broadcast channels can be accessed, it is mostly the elite members of the populace in each respective country who can access them. For example, alternative information and entertainment that the SABC claims to be providing to Africans through these channels is thus limited and 'niche marketed' to the 'national information haves' in the respective African nations. In essence the right to access to information is made to mean the right for those who have got resources to obtain information.

The regionalisation of South African media into African media space is not only elitist, but also promotes individual 'subscription' to information. This practice is permitted by the international communication law and has been criticised by developing countries. 
Developing countries argue that international communication law gives prominence to rights of the individual over the rights of the groups or community.

\section{References}

Africa2Africa. [0]. Available <http://www.africa2africa.co.za/introduction. htm>. 10 Oct. 2002.

Amin, H. "Egypt and the Arab world in the satellite age". Sinclair, P., Jacka, E. and Cunningham, S. ed. Global television: peripheral vision. (New York: Oxford University Press, 1996): 103-124.

Bird, W. "Here is the news: a comparison of e-tv and SABC 3 news". Media Mask 4.1 (1999): 14-32.

Burger, G. "Media, democracy in southern Africa". African Review of Political Economy 78 (25 Dec. 1998): 599-610.

Borman, E. and Schoonraad, N. International communication. Only study guide for 305, Department of Communication, University of South Africa: Pretoria, 2001.

Boyd-Barret, O. "Cultural dependency and the mass media". Gurevitch, M., Bennet, T., Curran, J. and Woollacott, J. eds. Culture, society and the media. (London: Methuen, 1982).

CMNALL-E/301. Department of Communication, UNISA: Pretoria, 1999.

Chadla, K. and Kavoori, A. "Media imperialism revisted: some findings from the Asian case". Media, culture and Society 22 (2000):415-432.

Fejes, F. "Media imperialism: an assessment". Media, Culture and Society 3 (1981): 281-289.

Fourie, J. P. and Oosthuizen, L. M. "Media imperialism: the New World Information and Communication Order". Fourie, J. P. ed. Media studies: institutions, theories and Issues. Lansdowne 1 (Cape Town: Juta, 2001): 415- 446.

Galtung, J. "A structural theory of imperialism". Journal of Peace Research, 8.2 (1971): 91-94. 
Gher, L. A. "Effects of transnational television programming on world wide cultural Diversity". Prosser, M. H and Sitaram, K. S. eds. Civic discourse: intercultural, international, and global media. (Stamford and Conn: Ablex Publishing Corporation, 1999): 211-227.

Hamelink, C. Cultural autonomy in global communications: planning national information policy. New York: Longman, 1983.

Jensen, M. "Sub-Saharan Africa". World Communication and information report 1999 (Paris: UNESCO Publishing, 1999): 180-196.

Kandjii, K. The role of the SABC in reclaiming the "public sphere" for Africa media. (paper read at the Freedom of Expression Institute workshop on the Corporatisation of the SABC). Unpublished, 2001.

Kareithi, P. “The white man's burden”. Rhodes journalism review 20 (Aug. 2001): 6-9.

Kumar, R. "Cultural imperialism in foreign television". Prosser, M.H. and Sitaram, K. S. eds. Civic discourse: intercultural, international, and global media. (Stamford and Conn: Ablex Publishing Corporation, 1999): 285299.

Lee, C. Media imperialism reconsidered: the homogenizing of television culture. London: Sage publications, 1979.

Mapukata, R. P. N. A comparative analysis of the content and framing of Nguni and English news as presented on SABC1 and SABC 3, 13 Jul.-13 Aug. 1998. Masters dissertation: University of Natal, 1998.

McPhail, T. L. Global communication: theories, stakeholders, and trends. Boston, MA: Allyn and Bacon, 2002.

MISA. Southern African media directory 2001/2. Media Institute of Southern Africa, 2002.

Musa, M. "From optimism to reality: an overview of Third World news agencies". Golding, P. and Harris, P. eds. Beyong Cultural imperialism. (London: Sage publications, 1997): 117-146.

Paterson, C. A. "Reform or re-colonisation? The overhaul of African television". African Review of political economy, 78 (25 Dec. 1998): 571583. 
Pendakur, M. and Subramanyam, R. "Indian cinema beyond national borders". Sinclair, P., Jacka, E. and Cunningham, S. eds. Global television: peripheral vision. (New York: Oxford University Press, 1996): 67-82.

Schiller, H. I. Communication and cultural domination. New York: International Arts \& Sciences Press, 1976.

Shaw, T. M. "Globalisation, regionalism and the south in the 1990s: towards a new political Economy of development". The European Journal of Development Research, 7.2 (Dec. 1995):257-275.

SABC Africa. [0]. Available: <http: //www.africanews.sabc.co.za/home. htm $>2001 / 09 / 04$.

Servaes, J. , Lie, R. and Terzis, G. Introduction: international communication: from media Imperialism to cultural globalisation. Study guide for paper 1 of the Masters Degree of Arts in International Communication, Department of Communication, UNISA: Pretoria, 2000.

Sinclair, J. "Neither West not Third World: the Mexican television industry within NWICO Debate". Media, culture and society, 12 (1990): 343-360.

Sinclair, J. "Decentering of cultural imperialism: Televia-ion and Globoization in the LatinWorld". Jacka, E. ed. Continental shifts: globalisation and culture. (Double Bay, N.S.W.: Local consumption publications 1992): 99-116.

Sonderling, S. "Development communication". Intercultural, development and health communication, only study guide for COM 204-8. Department of Communication. (UNISA: Pretoria, 2000).

South Africa Yearbook 2001/02. Pretoria: Government Communication and Information Systems (GCIS), 2001.

South Africa Broadcasting Corporation. SABC Africa and Africa2Africa: strategic planning session report: $4^{\text {th }}-5^{\text {th }}$ April 2001. Internal document, 2001.

Stevenson. R. L. Communication, development and the Third World: the global politics of information. Lanham: University Press of America, 1993.

Straubhaar, J. D. and Viscasillas, G. “The reception of telenovelas and other Latin American genres". Studies in Latin American popular culture 10 (1991): 191-214. 
314 Musa Ndlovu, The Meaning of South African Media's...

Teer-Tomaselli, R. "Nation building, social identity and television in a changing media Landscape". Kriger, R. and Zegeye, A. ed. Culture in the new South Africa 2 (Cape Town: Kwela books and SA History online, 2001):117-137.

Tomlison, J. "Cultural globalisation and cultural imperialism”. Mohammadi, A. ed. International communication and globalisation. (London: Sage, 1997).

Tsedu, M. "SABC's Africa channel leads in covering continent”. The Star. 7 Aug. 2002.

Van der Veur, P. R. "Broadcasting and political reform”. Hydèn, G., Leslie, M. and Ogundimu, F. F. eds. Media and democracy in Africa. (New Jersey: Transaction publishers, 2002): 81-105.

White, L. A. "Reconsidering cultural imperialism theory. Global Fusion 6 (Spring/Summer, 2001):1-2.

Wigston, D. "A South African media map". Fourie, J. P. ed. Media studies: institutions, theories and Issues. Lansdowne 1(Cape Town: Juta, 2001): 3-104.

[Received in 30/07/2011. Approved in 22/11/2011] 